\title{
Correction to: Intellectual capital-based performance improvement: a study in healthcare sector
}

Simona Alfiero ${ }^{1}$, Valerio Brescia ${ }^{1 *}$ and Fabrizio Bert ${ }^{2}$

\section{Correction to: BMC Health Serv Res 21, 73 (2021) https://doi.org/10.1186/s12913-021-06087-y}

Following the publication of the original article [1], the authors identified an error in Table 3. The correct table is given below.

The original article has been corrected.

\section{Author details}

${ }^{1}$ Department of Management, C.so Unione Sovietica, University of Turin, 218 bis, Torino, Italy. ${ }^{2}$ Department of Public Health Sciences, University of Turin, Via Santena 5/bis, Torino, Italy.

Published online: 22 February 2021

\section{Reference}

1. Alfiero, et al. Intellectual capital-based performance improvement: a study in healthcare sector. BMC Health Serv Res. 2021;21:73.
Table 3 Efficiencies in the 16 regions in 2016 based on the SBM-CRS and SBM-VRS models

\begin{tabular}{llllll}
\hline No. & DMU & OTE-CRS & PTE-VRS & SE & RTS \\
\hline 1 & Piemonte & 0.4812 & 1.0000 & 0.4812 & Decreasing \\
2 & Lombardia & 0.4154 & 0.9474 & 0.4385 & Decreasing \\
3 & Veneto & 0.5690 & 1.0000 & 0.5690 & Decreasing \\
4 & Liguria & 0.5667 & 1.0000 & 0.5667 & Decreasing \\
5 & Emilia Romagna & 0.4152 & 0.9844 & 0.4218 & Decreasing \\
6 & Toscana & 0.5208 & 1.0000 & 0.5208 & Decreasing \\
7 & Umbria & 0.5156 & 1.0000 & 0.5156 & Decreasing \\
8 & Marche & 0.4903 & 0.9593 & 0.5111 & Decreasing \\
9 & Lazio & 0.7706 & 0.9857 & 0.7818 & Decreasing \\
10 & Abruzzo & 0.4375 & 0.9481 & 0.4614 & Decreasing \\
11 & Molise & 1.0000 & 1.0000 & 1.0000 & Constant \\
12 & Campania & 0.7184 & 0.7306 & 0.9833 & Decreasing \\
13 & Puglia & 1.0000 & 1.0000 & 1.0000 & Constant \\
14 & Basilicata & 0.7726 & 1.0000 & 0.7726 & Decreasing \\
15 & Calabria & 0.7395 & 0.8443 & 0.8759 & Decreasing \\
16 & Sicilia & 0.7611 & 0.9160 & 0.8309 & Decreasing
\end{tabular}

Descriptive statistics of the efficiency score

\begin{tabular}{llll} 
& OTE-CRS & PTE-VRS & SE \\
Average & 0.636 & 0.957 & 0.671 \\
Max & 1.0000 & 1.0000 & 1.0000 \\
Min & 0.415 & 0.731 & 0.422 \\
St. Dev & 0.192 & 0.074 & 0.215 \\
\hline
\end{tabular}

The original article can be found online at https://doi.org/10.1186/s12913021-06087-y

*Correspondence: valerio.brescia@unito.it

'Department of Management, C.so Unione Sovietica, University of Turin, 218 bis, Torino, Italy

Full list of author information is available at the end of the article

(c) The Author(s). 2021 Open Access This article is licensed under a Creative Commons Attribution 4.0 International License, which permits use, sharing, adaptation, distribution and reproduction in any medium or format, as long as you give appropriate credit to the original author(s) and the source, provide a link to the Creative Commons licence, and indicate if changes were made. The images or other third party material in this article are included in the article's Creative Commons licence, unless indicated otherwise in a credit line to the material. If material is not included in the article's Creative Commons licence and your intended use is not permitted by statutory regulation or exceeds the permitted use, you will need to obtain permission directly from the copyright holder. To view a copy of this licence, visit http://creativecommons.org/licenses/by/4.0/ The Creative Commons Public Domain Dedication waiver (http://creativecommons.org/publicdomain/zero/1.0/) applies to the data made available in this article, unless otherwise stated in a credit line to the data. 